\title{
An Isolate of Apple stem grooving virus Associated with Cleopatra Mandarin Fruit Intumescence
}

\author{
Osvaldo Lovisolo $^{1}$, Gian Paolo Accotto ${ }^{1}$, Vera Masenga ${ }^{1}$, Addolorata Colariccio ${ }^{2}$ \\ ${ }^{1}$ Istituto di Virologia Vegetale del CNR, Strada delle Cacce 73, CAP 10135, Torino, Italia, e-mail: o.lovisolo@ifa.to.cnr.it; \\ ${ }^{2}$ Centro de Sanidade Vegetal, Instituto Biologico de São Paulo, Av. Conselheiro Rodrigues Alves, 1252, CEP 04014-002, \\ São Paulo, SP, e-mail: colariccio@biologico.br
}

(Accepted for publication on 25/11/2002)

Corresponding author: Addolorata Colariccio

LOVISOLO, O., ACCOTTO, G.P., MASENGA, V., COLARICCIO, A. An isolate of Apple stem grooving virus associated with Cleopatra mandarin fruit intumescence. Fitopatologia Brasileira 28:054-058. 2003.

\begin{abstract}
A citrus tatter leaf isolate (CTLV-Cl) of Apple stem grooving virus (ASGV) has been found to be associated with a fruit rind intumescence in Cleopatra mandarin (Citrus reshni) in Limeira (SP). The CTLV-Cl was mechanically transmitted to the main experimental herbaceous hosts of CTLV. Chenopodium quinoa and C. amaranticolor reacted with local lesions and systemic symptoms while other test plants reacted somewhat differently than what is

reported for CTLV. A pair of primers designed for specific detection of ASGV and CTLV amplified the expected $801 \mathrm{bp}$ fragment from the CTLV-Cl-infected plants. Typical capillovirus-like particles were observed by the electron microscope in experimentally infected $C$. quinoa and C. amaranticolor leaves. RT-PCR.

\section{RESUMO}

Isolado do Apple stem grooving virus associado a intumescências em frutos de tangerina Cleópatra

A presença de intumescências em frutos de tangerina Cleópatra (Citrus reshni) observadas em Limeira (SP), foram associadas ao Citrus tatter leaf (CTLV-Cl), um isolado do virus do acanalamento do lenho da maceira (Apple stem grooving virus, ASGV). O CTLV-Cl foi transmitido mecanicamente para as principais hospedera experimentais do CTLV. Chenopodium quinoa

e C. amaranticolor reagiram com lesões locais e sintomas sistêmicos, enquanto as demais reagiram ligeiramente diferente do relatado para CTLV. Um par de primers desenhados para CTLV e ASGV amplificaram um fragmento de $801 \mathrm{pb}$, conforme o esperado, a parteir de plantas herbaceas infetadas com o CTLV-Cl. Particulas do tipo capillovirus foram observadas ao microscópio eletrônico, em folhas de Chenopodium quinoa e C. amaranticolor experimentalmente infetadas.
\end{abstract}

\section{INTRODUCTION}

The virus formerly known as Citrus tatter leaf virus (CTLV) has now been included within the species Apple stem grooving virus (ASGV) family Closteroviridae, genus Capillovirus (van Regenmortel et al., 2000). However, as the literature on the two viruses is largely separate and under the two different names, the acronyms CTLV and ASGV will be used to refer to these viruses.

While the genome properties of CTLV are well known (Ohira et al., 1995), the biological proprieties are still obscure and difficult to completely clarify, mainly because the diseases in citrus (Citrus spp.) have a long incubation period and are mainly associated with bud-union incompatibility. The reaction of experimental herbaceous hosts is also rather variable, and few strain comparisons have been done. Citrange stunt (Wallace \& Drake, 1968) was shown to be caused by isolates of ASGV that vary somewhat in biological properties (Roistacher et al., 2000; Miyakawa \& Ito, 2000).

CTLV was first reported in latently infected Meyer lemon [Citrus limon (L.) Burn.f.], a supposed hybrid of Citrus limon, introduced to California from China in 1908 (Wallace \& Drake, 1962). CTLV latently infects most cultivated citrus when grown on their own roots. Disease appears when symptomless infected plants are grafted on trifoliate orange [Poncirus trifoliata (L.) Raf.] or trifoliate orange hybrids, such as Rusk, Troyer or Carrizo citrange $(P$. trifoliata $x$ C. sinensis) or Citremon (P. trifoliata $x$ C. limon). Grafted trees show stunting, chlorosis and bud-union incompatibility, resulting in bud-union creases and trunk fluting of the rootstock. Typical tatter leaf and chlorotic leaf symptoms are produced in C. excelsa Webster, Mexican lime [C. aurantifolia (Christm.) Swing.] and Rusk citrange, when experimentally graft-inoculated, one to six months after inoculation (Frison \& Taher, 1991; Roistacher, 1991; Miyakawa \& Ito, 2000).

Fruit rind intumescence was found in Cleopatra mandarin (Citrus reshni Hort. ex Tan.) during surveys for Citrus leprosis virus (CiLV) a putative family Rhabdoviridae in Limeira, SP (Lovisolo et al., 2000). It was also found to be associated with an isolate of ASGV nominated CTLV-Cl. We report field observations and investigations on mechanical 
An isolate of Apple stem grooving virus associated with Cleopatra ...

transmission to herbaceous test plants, electron microscopy, RT-PCR amplification and analysis with CTLV primers.

\section{MATERIALS AND METHODS}

\section{Mechanical transmission}

The virus was isolated as described for CiLV (Colariccio et al., 1995). Symptomatic parts of the fruit rinds of Cleopatra mandarin (Figure 1d, e) were inoculated into a series of test plants of CiLV and other citrus viruses. The inoculum was obtained by grinding the fruit rinds in liquid nitrogen and adding, during thawing, from 0.5 to $1 \%$ activated carbon and $0.05 \mathrm{M}$ phosphate buffer $\mathrm{pH} 7$, containing $0.005 \mathrm{M}$ Na-Dieca, 0.001 M Na-EDTA, and 0.005 M Na-thioglycolate (about one part of tissue in four parts of buffer, w/v). Further transmission tests to investigate host range were done, omitting the grinding in liquid nitrogen, in insect-proof greenhouses kept at a mean temperature of $21-24{ }^{\circ} \mathrm{C}$.

\section{Electron microscopy}

Samples of systemically infected leaves of Chenopodium amaranticolor Coste \& Reyn and C. quinoa Willd were homogenized in cold $0.1 \mathrm{M}$ phosphate buffer $\mathrm{pH}$ 7 containing $2 \%(\mathrm{w} / \mathrm{v})$ polyvinylpyrrolidone. Then they were negatively stained in $1 \%$ aqueous uranyl acetate and viewed in a Philips CM 10 electron microscope.

\section{RT-PCR}

A pair of primers was designed based on the CTLV sequence (GenBank acc. No. D16681), which amplified an 801 bp DNA fragment in the region of the CP gene. They were: CTL5607 (+) 5'- CCCTCTCAGCTAGAATTGAA -3' and CTL6407 (-) 5'- CAGGCATGTCAACCTGCAAG -3'. This pair of primers is also homologous to the ASGV sequence (acc. No. D14995), except for a single mismatch (G in ASGV, A in CTLV) at the eighth nucleotide of CTL5607 (+). Chenopodium quinoa leaves with local lesions collected ten days post inoculation, and C. quinoa and C. amaranticolor leaves with systemic infection collected 30-40 days post inoculation were used for RNA extraction. Total RNA was extracted from $0.1 \mathrm{~g}$ using the RNAWIZ reagent (Ambion) and diluted to $0.1-0.5 \mu \mathrm{g} / \mu 1$. One $\mu 1$ was used for RT-PCR with the One Step RT-PCR System (Life Technologies/Invitrogen), according to Louro et al. (2000). Briefly, following RNA denaturation $\left(5 \mathrm{~min}\right.$ at $\left.65^{\circ} \mathrm{C}\right)$, the reaction mix was reversetranscribed $\left(30 \mathrm{~min}\right.$ at $\left.50{ }^{\circ} \mathrm{C}\right)$, denatured $\left(30 \mathrm{~s}\right.$ at $\left.95{ }^{\circ} \mathrm{C}\right)$, and 35 cycles of amplification $\left(15 \mathrm{~s}\right.$ at $95{ }^{\circ} \mathrm{C}, 30 \mathrm{~s}$ at $50{ }^{\circ} \mathrm{C}, 1 \mathrm{~min}$ at $72{ }^{\circ} \mathrm{C}$ ) were performed. An aliquot of the reaction was finally analyzed on $1.2 \%$ agarose gel.

\section{RESULTS}

\section{Field observations}

The fruit rind intumescence in Cleopatra mandarin (Figure 1d, e) occurred on plants also showing CiLV symptoms on the leaves. In previous surveys, Cleopatra

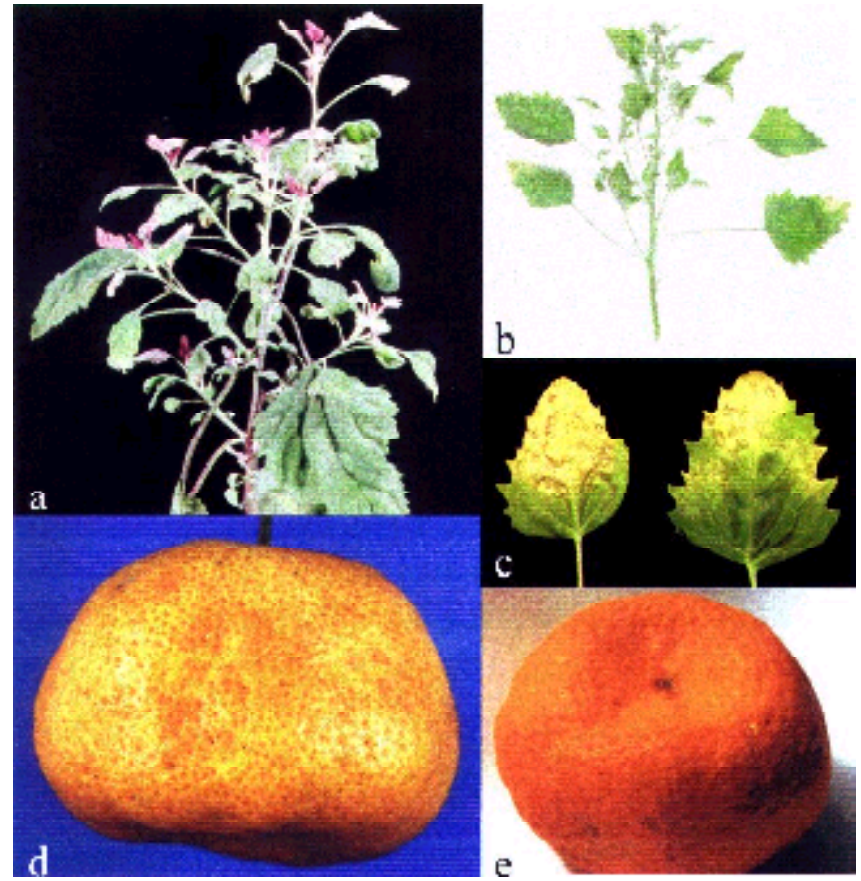

FIG. 1 - Symptoms caused or associated to CTLV-Cl: a) Systemic symptoms on Chenopodium amaranticolor, about two months after inoculation; b) Systemic on Chenopodium quinoa, about two months after inoculation; c) Local lesions on $C$. quinoa, ten days after inoculation; d) Intumescent areas on a fruits of Cleopatra mandarin (Citrus reshni), in May; e) Intumescent areas in September.

mandarin was found to be a new natural host of CiLV with symptoms on the leaves, less frequently on the stems, but never on the fruits (Lovisolo et al., 2000).

The intumescent areas on the fruits were large, covering half or more of the fruit surface; their color was paler than the normal orange of healthy fruits. No association was found between the intumescent areas, CiLV infection, fungus attacks, or arthropod feeding injuries.

The infected plants were Cleopatra mandarin rootstocks on which Murcott tangor (Citrus reticulata x $C$. sinensis) scions had been grafted, and then cut back, leaving the Cleopatra mandarin trees.

\section{Mechanical transmission to herbaceous hosts}

CTLV-Cl was isolated from the symptomatic fruit rind through mechanical inoculation to herbaceous test plants. The virus was mechanically transmitted to the herbaceous plants (Table 1), in which the type of symptoms, the minimum incubation period (days for symptoms appearance) and the results of back inoculation are listed.

The most useful test plants were C. quinoa and $C$. amaranticolor, on which the virus caused local lesions (Figure 1c) and systemic symptoms (Figure 1a, b), particularly severe with leaf deformation and general growth reduction. Infected plants tended to recover two-three months after infection. 
TABLE 1 - Experimental host reactions of Citrus tatter leaf virus (CTLV-Cl) isolated from Cleopatra mandarin (Citrus reshni)

\begin{tabular}{|c|c|c|c|c|}
\hline Test plant & Local symptoms & $\begin{array}{l}\text { Systemic } \\
\text { symptoms }\end{array}$ & $\begin{array}{c}\text { Days for } \\
\text { symptoms } \\
\text { appearance } \\
\end{array}$ & $\begin{array}{c}\text { Back inoculation to } \\
\text { C. quinoa from } \\
\text { local/systemic symptoms }\end{array}$ \\
\hline \multicolumn{5}{|l|}{ Amaranthaceae } \\
\hline Amaranthus tricolor $\mathrm{L}$. & 0 & 0 & & \\
\hline Gomphrena globosa L. & er.n.l.le. & 0 & 9 & $+/+$ \\
\hline \multicolumn{5}{|l|}{ Apocynaceae } \\
\hline Catharanthus roseus (L.) G. Don & 0 & 0 & & - \\
\hline \multicolumn{5}{|l|}{ Chenopodiaceae } \\
\hline Chenopodium amaranticolor & er.s.l.n.le. & ap. & 7 & $+/+$ \\
\hline C. quinoa & l.c./n.rs.le. & mo.ap. & 5 & $+/+$ \\
\hline \multicolumn{5}{|l|}{ Cucurbitaceae } \\
\hline Citrullus lunatus (Thumb.) Mansf. & 0 & 0 & & - \\
\hline Cucumis sativus L. & 0 & 0 & & - \\
\hline Cucurbita pepo L. & 0 & 0 & & + \\
\hline \multicolumn{5}{|l|}{ Labiatae } \\
\hline Ocimum basilicum $\mathrm{L}$. & 0 & 0 & & \\
\hline \multicolumn{5}{|l|}{ Leguminosae } \\
\hline Glycine $\max (\mathrm{L}$.$) Merr$ & 0 & 0 & & \\
\hline Phaseolusvulgaris 'Saxa' & s.l.n.le. & 0 & 8 & $+/-$ \\
\hline Vigna unguiculata 'Black' & s.l.n.le. & 0 & 10 & $+/+$ \\
\hline \multicolumn{5}{|l|}{ Myrtaceae } \\
\hline Psidium guajava $\mathrm{L}$. & 0 & 0 & & \\
\hline \multicolumn{5}{|l|}{ Pedaliaceae } \\
\hline Sesamum indicum $\mathrm{L}$. & 0 & 0 & & \\
\hline \multicolumn{5}{|l|}{ Solanaceae } \\
\hline Datura stramonium L. & 0 & 0 & & - \\
\hline Nicotiana benthamiana & 0 & 0 & & - \\
\hline N. clevelandii A. Gray & 0 & 0 & & + \\
\hline N. megalosiphon Henrck \& Muell & 0 & 0 & & - \\
\hline N. occidentalis & 0 & 0 & & - \\
\hline N. rústica $\mathrm{L}$. & 0 & 0 & & - \\
\hline N. tabacum 'White Burley' L. & 0 & 0 & & - \\
\hline Petunia $x$ hybrida Vilm. & 0 & 0 & & - \\
\hline \multicolumn{5}{|l|}{ Tetragoniaceae } \\
\hline Tetragonia tetragonioides (Pall.) Ktze & 0 & 0 & & - \\
\hline
\end{tabular}

Erratic local symptoms were observed on C. amaranticolor and Gomphrena globosa L. Phaseolus vulgaris L. 'Saxa' and Vigna unguiculata (L.) Walp. 'Black' reacted with necrotic local lesions rather irregularly. Systemic symptoms were never seen, but the virus could be re-isolated from uninoculated young leaves of $V$. unguiculata.

\section{Electron microscopy}

Few capillovirus-like particles were seen in the homogenized leaf tissues of $C$. amaranticolor and C. quinoa (Figure 2a). Most of these particles appeared broken or trapped in host material.

\section{RT-PCR}

The CTLV-Cl specific 801 bp DNA fragment was amplified from total RNA extracted from both C. quinoa (local and systemic infection) and $C$. amaranticolor (systemic infection), as well as from the ASGV positive control (Figure 2b). No extra bands were visible.

\section{DISCUSSION}

Our results on host range and symptoms, RT-PCR detection of a specific DNA fragment, and virus morphology, show that the virus isolated from Cleopatra fruit with rind intumescence (CTLV-Cl) is an isolate of ASGV. CTLV has never been reported in Cleopatra mandarin, but Garnsey (1999) in a table on "Susceptibility to systemic diseases in citrus trees on different rootstocks" lists Cleopatra mandarin in the category of "Tolerant or resistant" to CTLV. Fruit rind intumescence, if experimentally reproduced, would be the first symptom reported for CTLV-infected Cleopatra mandarin. CTLV was isolated from fruit rind of Meyer lemon, but no symptoms were reported (Yarwood, 1963).

Both CTLV-Cl and the previously known CTLV isolates infected $C$. quinoa and C. amaranticolor with rather similar local and systemic symptoms, while other test plants reacted somewhat differently from what is reported for CTLV. The main differences between these isolates were observed 
An isolate of Apple stem grooving virus associated with Cleopatra ...
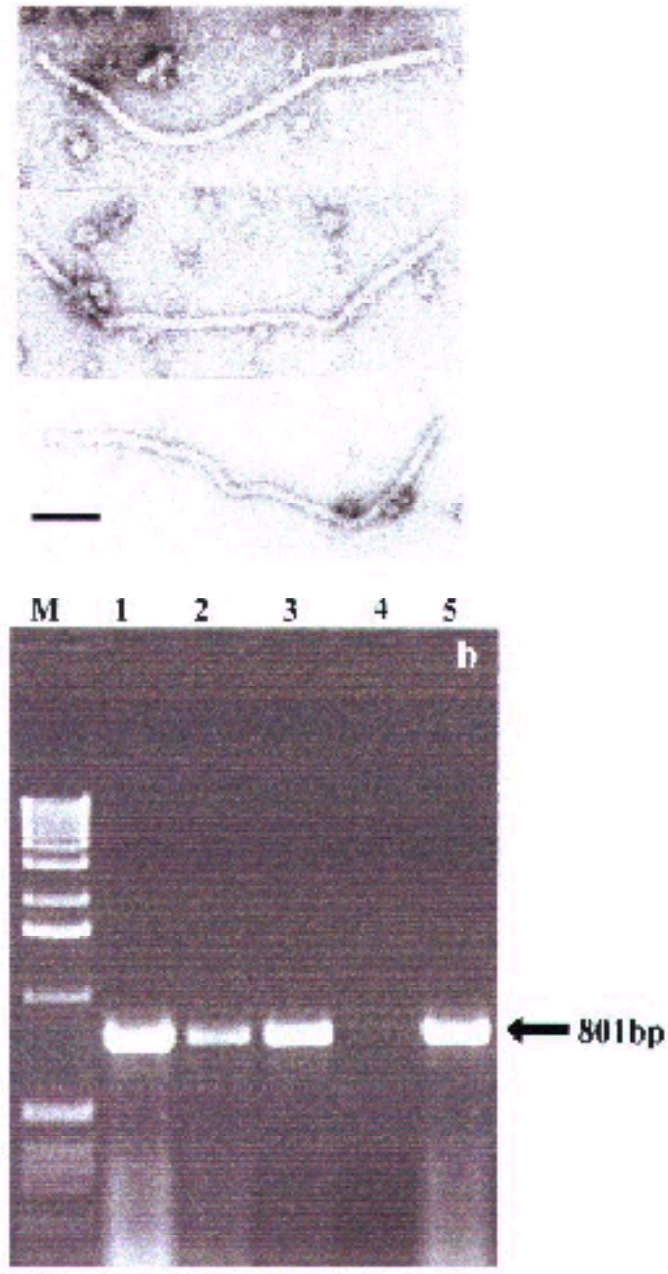

FIG. 2 - a) Capillovirus-like particles in homogenized leaf tissues of Chenopodium quinoa stained with $1 \%$ uranyl acetate. Bar $=100 \mathrm{~nm}$; b) Agarose gel electrophoresis of DNA fragments obtained by RT-PCR from locally (lane 1) or systemically (lane 2) infected $C$. quinoa, systemically infected $C$. amaranticolor (lane 3), uninoculated (lane 4) and Apple stem groving virus (ASGV)-infected (lane 5) $C$. quinoa. Lane $M$ contains size markers (1Kb DNA ladder, Life Technologies). The arrow indicates the position of the ASGV/CTLV-specific 801 bp DNA fragment.

in $V$. unguiculata and $P$. vulgaris. CTLV-Cl caused small local lesions in $V$. unguiculata and $P$. vulgaris French bean, which were different from and less numerous than the ones illustrated by Semancik \& Weathers (1965) and Roistacher (1991) for CTLV. The isolate described by Semancik \& Weathers (1965) induced more rapid and severe reactions in some hosts than CTLV-Cl did, but it is known that several factors may influence the symptoms expression of viruses. Roistacher (1991) mentions that warm temperatures may mask symptom development of CTLV.

The one-step RT-PCR procedure reported here was only applied for total RNA extracted from mechanically inoculated experimental hosts. However, the method appeared reliable and robust, and will probably be useful for rapid screening of field citrus samples, as reported by Hailstones $e t$ al. (2000).

CTLV is widespread in China, Taiwan, Japan, and has also been reported in Korea, South Africa, Australia and the USA, where it was first found in Meyer lemon (Wallace \& Drake, 1962; OEPP/EPPO, 1992). CTLV could have been introduced into other countries where Meyer lemons (symptomless hosts) have been imported, but that does not mean that the virus underwent secondary spread. This may be the case of Morocco where CTLV was found by Wallace (1975), but never reported again.

The geographic distribution of isolates of ASGV infecting Rosaceae is wider than that of the former CTLV isolates. According to Lister (1970; 1996), ASGV has been reported in Australia, China, India, Italy, Japan, the Netherlands, New Zealand, North America, Portugal, the $\mathrm{UK}$, and is probably present worldwide in apples. ASGV was detected in Brazil (Betti et al., 1995) in samples of apple Virginia Crab (Mallus sylvestris Mill.) from commercial plantations in Angatuba and Paranapanema in the State of São Paulo, using woody indicator hosts. Recently, Nickel et al. (1999; 2001), using RT-PCR and ISEM assays were able to detected ASGV in apple mother stocks and cultivars introduced to Southern Brazil. The origins of the infected plants (20\% in a restricted survey) were São Joaquin (RS, Brazil), the Netherlands, Japan, and Caçador (SC, Brazil).

CTLV was previously reported in Meyer lemon fruits (Yarwood, 1963), and now in Cleopatra mandarin fruits. Further investigations will be necessary to find out if CTLV is seed-transmissible in citrus, as is the case for lily (Lilium candidum L.) seeds and some herbaceous test plants (Inouye et al., 1979). CTLV is also known to be easily sap transmissible through knife cuts from citron (Citrus medica L.) to citron (Roistacher, 1991). Nothing is known about the natural transfer of ASGV from Rosaceae to citrus plants and to lily, or vice-versa, but agronomic contamination of citrus from apple or pear (Pyrus communis L.) could have occurred via grafting knives (Herron \& Skaria, 2000). CTLV can not be eliminated with shoot-tip grafting (STG) alone, but needs the combination of thermotherapy and STG (Song et al., 1999). CTLV is included in the list of the viruses that should be checked for the safe movement of citrus germplasm (Frison \& Taher, 1991).

\section{ACKNOWLEDGMENTS}

Thanks are due to A.N. Adams (Horticulture Research International, East Malling, Maidstone, UK) for providing Apple stem grooving virus, to M. Conti and R.G. Milne (Istituto di Fitovirologia applicata, Torino, Italy) for critical reading and revising the text, and to A. Alves de Carvalho Junior, Post Doctor FAPESP, Instituto Biologico, São Paulo, Brazil) for electronic handling of picture files. 


\section{LITERATURE CITED}

BETTI, J.A., DEL CASTRO, J.L. \& MULLER, G.W. Detecção de viroses da macieira em São Paulo com doze indicadoras lenhosas. Summa Phytopathologica 21: 49. 1995 (Abstract).

COLARICCIO, A., LOVISOLO, O., CHAGAS, C.M., GALLETI, S.R., ROSSETTI. V. \& KITAJIMA, E.W. Mechanical transmission and ultrastructural aspects of citrus leprosis disease. Fitopatologia Brasileira 20:208-213. 1995.

FRISON, E.A. \& TAHER, M.M. (Eds.). FAO/IBPGR Technical Guidelines for the Safe Movement of Citrus Germplasm. Food and Agriculture Organization of the United Nations \& International Board for Plant Genetic Resources, Rome (I). 1991.

GARNSEY, S.M. Systemic Diseases. In Timmer, L.W. \& Duncan, L.W (Eds.). Citrus Health Management, New York. APS Press, 1999. pp.95-106.

HAILSTONES, D.L., BRYANT, K.L., BROADBENT, P. \& ZHOU, C. Detection of Citrus tatter leaf virus with reverse transcriptionpolymerase chain reaction (RT-PCR). Australasian Plant Pathology 29:240-248. 2000

HERRON, C.M. \& SKARIA, M. Further studies on Citrus tatter leaf virus in Texas. Proceedings Conference IOCV, Riverside (US) 14:185-194. 2000.

INOUYE, N., MAEDA, T. \& MITSUHATA K. Citrus tatter leaf virus isolated from lily. Annals of the Phytopathological Society of Japan 45:712-720. 1979.

LISTER, R.M. Apple stem grooving virus, C.M.I./A.A.B. Description of Plant Viruses, No 31.1970.

LISTER, R.M. Apple stem grooving virus. In: Brunt, A.A., Crabtree, K., Dallwitz, M.J., Gibbs, A.J. \& Watson, L. (Eds). Viruses of Plants, Wallingford, U.K. CAB International 1996. pp.105-108.

LOURO, D., ACCOTTO, G.P. \& VAIRA, A.M. Occurrence and diagnosis of Tomato chlorosis virus in Portugal. European Journal of Plant Pathology 106:589-592. 2000.

LOVISOlO, O., COLARICCIO, A \& MASENGA, V. New experimental hosts and further information on citrus leprosis virus. Proceedings Conference IOCV, Riverside (US) 14:164-173. 2000.

MIYAKAWA, T. \& ITO, T. Tatter Leaf - Citrange Stunt. In: Timmer, L.W., Garnsey, S.M. \& Graham, J.H. (Eds.). Compendium of Citrus Diseases, Second Edition, St. Paul (US). APS Press. 2000.

NICKEL, O., JELKMANN, W., \& KUHN, G.B. Occurrence of Apple stem grooving virus capillovirus in Santa Catarina, Brazil, detected by RT-PCR. Fitopatologia Brasileira 24:444-446. 1999.
NICKEL, O., FAJARDO, T.V.M., JELKMANN, W., \& KUHN, G.B. Sequence analysis of the capsid protein gene of an isolate of Apple stem grooving virus, and its survey in Southern Brazil. Fitopatologia Brasileira 26: 655-659. 2001.

OEPP/EPPO. Citrus tatter leaf capillovirus. In Smith, I.M., McNamara, D.G., Scott, P.R. \& Harris, K.M. (Eds.) Quarantine pest for Europe, Wallingford, UK, CAB International 1992. pp. 904908.

OHIRA, K, NAMBA, S., ROZANOV, M., KUSUMI, T. \& TSUCHIZAKI, T. Complete sequence of an infectious full-length cDNA clone of citrus tatter leaf capillovirus: Comparative sequence analysis of capillovirus genomes. Journal of General Virology 76:2305-2309. 1995

ROISTACHER, C.N. Graft-Transmissible Diseases of Citrus. Handbook for detection and diagnosis. Food and Agriculture Organization of the United Nations, Rome (I). 1991.

ROISTACHER, C.N., BASH, J. \& GUMPF, D.J. Continued attempts over a 22-year period to separate components of the citrus tatter leaf-citrange stunt virus complex. Proceedings Conference IOCV, Riverside (US) 14:179-184. 2000.

SEMANCIK, J.S. \& WEATHERS, L.G. Partial purification of a mechanically transmissible virus associated with tatter leaf of citrus. Phytopathology 55:1354-1358. 1965.

SONG, R.L., WU, R.J. \& KE, C. Elimination of the main citrus and virus-like diseases by shoot-tip grafting. Acta Phytopathologica Sinica 29:275-279. 1999.

van REGENMORTEL, M.H.V., FAUQUET, C.M., BISHOP, D.H.L., CARSTENS, E.B., ESTES, M.K., LEMON, S.M., MANILOFF, J., MAYO, M.A., McGEOCH, D.J., PRINGLE, C.R. \& WICKNER, R.B. Virus Taxonomy. Seventh Report of the International Committee on Taxonomy of Viruses. San Diego, Academic Press. 2000.

WALLACE, J.M. Tatter leaf. In Bové, J.M. \& Vogel, R. (Eds.) Description and illustration of virus and virus-like diseases of citrus. A collection of colour slides, Paris (FR), SETCO-IRFA. 1975.

WALLACE, J.M. \& DRAKE, R.J. Tatter leaf, a previously undescribed virus effect on citrus. Plant Disease Reporter 46:211212. 1962

WALLACE, J.M. \& DRAKE, R.J. Citrange stunt and ringspot, two previously undescribed virus disease of citrus. Proceedings Conference IOCV, Riverside (US) 4:177-180. 1968.

YARWOOD, C.E. Mechanical transmission of a latent lemon virus. Phytopathology 53:1145. 1963 (Abstract). 